\title{
JAMES T. C. LIU
}

(1919-1993)

James T. C. Liu (Liu Tzu-chien) died at his home in Lawrenceville, New Jersey, on September 30, 1993, after a long illness. He was 74 . His family was from Kueiyang in Kweichow Province, China. He grew up in Shanghai and went to Beijing to attend Tsinghua University until it was forced to move south under the Japanese occupation. He then attended Yenching University. After Pearl Harbor, he was imprisoned with other Yenching faculty and students suspected of anti-occupation activities. Later, he often said he bore no bitterness because of his wartime sufferings. When the war was over, he went to Japan to serve on the staff of the Chinese judicial delegation to the International Tribunal at Tokyo. In part due to the influence of William Hung (Hung Yeh), his teacher at Yenching whom he always regarded as his mentor, James came to the United States to share his knowledge and pursue his research in recent political affairs. He received his $\mathrm{Ph.D}$. from the University of Pittsburgh in 1950 and taught there and elsewhere before joining the Stanford University faculty in 1960 . In 1965 he moved to Princeton University.

At Stanford James had a leading role in initiating a farsighted project that continues to benefit graduate students in Chinese studies and to promote academic and cultural exchange between the U.S. and Taiwan. Brought to realization in part by James's efforts, this initiative became the Inter-University Program for Chinese Language Studies in Taipei.

James established his leadership in the field of Sung history in 1959 with the publication of a little book entitled Reform in Sung China: Wang An-shib and bis new policies. It was the third book in what was to grow into the distinguished Harvard East Asian Series. In his research James had taken on one of the most controversial topics in the later imperial period and gave a convincing account of the complicated episode by using what he called a cross-sectional approach, drawing on a wide range of source materials. The book also was historiographically significant as one of the first works in a Western language to make full use of the burgeoning literature on Chinese history written by researchers in Japan as well as in China. His example was adopted by others, but it was James who particularly served as a continuing link for the exchanges between the U.S. and Japan in scholars and scholarship on China.

In his next books, James proved that he was one of the world's pre-eminent specialists on the Sung. He paid special attention to the pivotal eleventh-century poet, scholar, and official, Ou-yang Hsiu. Again drawing on a wide range of sources to define Ou-yang's multifaceted interests and career, James published his research in a volume in Chinese in 1963 (Hong Kong, New Asia College) and then rewrote it for readers of English in a version published in 1967 (Stanford University Press). His work on Ou-yang Hsiu exemplifies another way in which James served as an important link, this time between Western-style historical scholarship and historical research in China. As Deng Guangming pointed out in his preface for the volume of forty essays published in Kyoto to celebrate James's seventieth birthday, in his many lectures and meetings in China James emphasized the need to be broad and interdisciplinary in approach as a corrective to the sometimes narrow, technical, and doctrinaire training he saw there. At the same time, in guiding graduate students, 
he emphasized the need to master the primary sources before attempting grand interpretative generalizations. He will be remembered by his students not only for the careful training he provided, but also for the sage advice and assistance he so willingly provided.

Of course, James generalized. He made telling inferences based on the demise of the interest in polo-playing in the ninth century and on the changes in the Threecharacter Classic for elementary education. He proposed innovative terms, such as the "neo-traditional period" and "accommodative politics." He made innovative interpretations, most sweepingly in his argument about China Turning Inward at the beginning of the twelfth century (Harvard, 1988). A major part of his motive in this was his earnest desire to serve as still another type of link-between China's past and its present, and, he always hoped, its future.

James also sought to be a link between the U.S. and China, even when being a friend of the People's Republic of China made him a target of criticism in the U.S., just as his living in the U.S. made him a target in China. When he returned to China, he learned the circumstances of the deaths of his three brothers during the Cultural Revolution, but he showed no bitterness, even when Zhou Enlai referred to the "excesses" that had occurred.

James recognized that this role as a link put him in the middle between two positions; he alluded to this in the literary name he adopted for himself-Banbin, the "half-guest." Whether in the U.S., Japan, Europe, or China, he represented himself as in part a guest. But the name applied as well in all of his endeavors, in the sense of his visiting in a scholarly field or a historical period. He was a halfguest in the social sciences, and also in the humanities. Colleagues and graduate students who worked with him realized that with his immensely detailed knowledge of political events and historical materials, he was a major resource for understanding twentieth-century China; he had been visiting there during a tumultuous period. Equally, his detailed knowledge of the eleventh and twelfth centuries gave the impression of his having been a guest in the Sung dynasty. James played with this idea by adopting as his own the calligraphic style of the twelfth-century emperor Hui-tsung, with its forceful, exquisitely lean brushstrokes.

Finally, and most significantly, the implication of his being the "half-guest," of course, was that he was also half "at home" in all of his interests and scholarly pursuits, and Princeton University has been privileged that he made that home among us for more than twenty-five years.

ANDREW H. Plaks

Willard J. Peterson

HAI-TAO TANG

YING-SHIH YU

Princeton University 